\title{
Analisis Determinan Harga Saham Perusahaan Sektor Keuangan di Bursa Efek Indonesia Tahun 2019
}

*Mei Tresnawati ${ }^{1}$, Achmad Fauzi ${ }^{2},{ }^{* *}$ Mardi $^{3}$

1,2,3Universitas Negeri Jakarta

\section{ARTICLE INFO}

Article History:

Received: 04 June 2021

Accepted: 21 July 2021

Published: 21 July 2021

Keywords:

Debt to Equity Ratio, Return On

Equity, Earnings Per Share, Stock

Price

\begin{abstract}
This research aims to analyze the factors that can affect stock price of financial sector companies. Independent variables used in this research were dept to equity ratio (DER), return on equity (ROE) and earnings per share (EPS). Dependent variable was stock price measured by closing price. Population used in this research are financial sector companies listed Indonesian Stock Exchange in period 2019. Sample collected using purposive sampling method. The total of 57 companies were determined as sample during 2019. The method of analysis of this research using multiple linier regression. The result showed that debt to equity ratio has no effect on stock price, while return on equity and earning per share has positive effect on stock prices.
\end{abstract}

\section{ABSTRAK}

Tujuan penelitian ini untuk menganalisis faktor yang dapat mempengaruhi harga saham pada perusahaan sektor keuangan. Variabel independen yang digunakan dalam penelitian ini adalah rasio utang terhadap ekuitas (DER), rasio pengembalian modal (ROE), dan laba per saham (EPS). Variabel dependen adalah harga saham yang diukur dengan harga penutupan. Populasi yang digunakan dalam penelitian ini adalah perusahaan sektor keuangan yang terdaftar di Bursa Efek Indonesia pada periode 2019. Sampel dikumpulkan dengan menggunakan metode purposive sampling. Total 57 perusahaan ditentukan sebagai sampel selama 2019. Metode analisis penelitian ini menggunakan regresi linier berganda. Hasil penelitian menunjukkan bahwa rasio utang terhadap modal tidak memiliki pengaruh terhadap harga saham sedangkan rasio pengembalian modal dan laba per saham memiliki pengaruh positif terhadap harga saham.

\section{How to Cite:}

Tresnawati, Mei, Achmad Fauzi, dan Mardi. (2021). Analisis Determinan Harga Saham Perusahaan Sektor Keuangan di Bursa Efek Indonesia Tahun 2019. Jurnal Ilmiah Wahana Akuntansi, 16(1), 111-123. https://doi.org/10.21009/ wahana.16.017 
Mei Tresnawati, Achmad Fauzi, dan Mardi/ Jurnal Ilmiah Wahana Akuntansi, 16 (1) 2021, 111-123

\section{PENDAHULUAN}

Perkembangan pasar modal di Indonesia saat ini cukup pesat. Hal tersebut juga diimbangi dengan masyarakat yang mulai tertarik dan menyadari pentingnya melakukan investasi untuk menunjang perekonomian di masa depan, dikarenakan adanya pemenuhan kebutuhan yang semakin meningkat dan banyaknya ketidakpastian yang terjadi dalam kehidupan di masa depan (Handini \& Astawinetu, 2020). Dari temuan hasil survei yang dilakukan Manulife Asset Management bertajuk "Manulife Investor Sentimen Index (MISI)" Saham adalah salah satu instrumen pasar modal yang paling banyak dipilih dan diminati oleh investor terutama investor domestik. Hal ini dipengaruhi dari keuntungan yang diperoleh dalam investasi saham yang semakin menjanjikan seperti dividen dan capital gain (Putra \& Yadnya, 2016:3). Hal tersebut dikarenakan saham menjadi sekuritas yang dapat memberikan peluang keuntungan paling tinggi dibandingkan sekuritas lain di pasar modal (Widioatmodjo, 2014). Namun saham juga memiliki risiko yang tinggi pula karena saham bersifat high return-high risk. Oleh karena itu, investor perlu melakukan analisis saham secara tepat untuk meminimalisir risiko yang tidak diharapkan (Zulfikar, 2016).

Keuntungan suatu perusahaan dari investasi yang dilakukan merupakan salah satu faktor penting yang harus diperhatikan dalam melakukan investasi, karena akan mempengaruhi harga saham (Widioatmodjo, 2015). Perubahan harga saham sendiri yang terjadi setiap tahunnya tentu dipengaruhi oleh beberapa faktor (Zulfikar, 2016). Pike dalam (Astawinetu \& Handini, 2020) menyebutkan harga saham sendiri merupakan faktor yang mencerminkan tingkat pengembalian modal. Oleh karena itu, faktorfaktor yang mempengaruhi perubahan harga saham tersebut harus menjadi perhatian para investor sebelum menginvestasikan dananya pada saham (Ariyani et al., 2018). Untuk mengetahui perubahan atau pergerakan harga saham, investor umumnya mengamati melalui indeks harga saham. Di Indonesia salah satu indeks pasar saham yang digunakan oleh Bursa Efek Indonesia adalah Indeks Harga Saham Gabungan atau disingkat dengan IHSG, dalam bahasa inggris disebut Indonesia Composite Index atau IDX Composite (Sunaryo, 2019: 17).

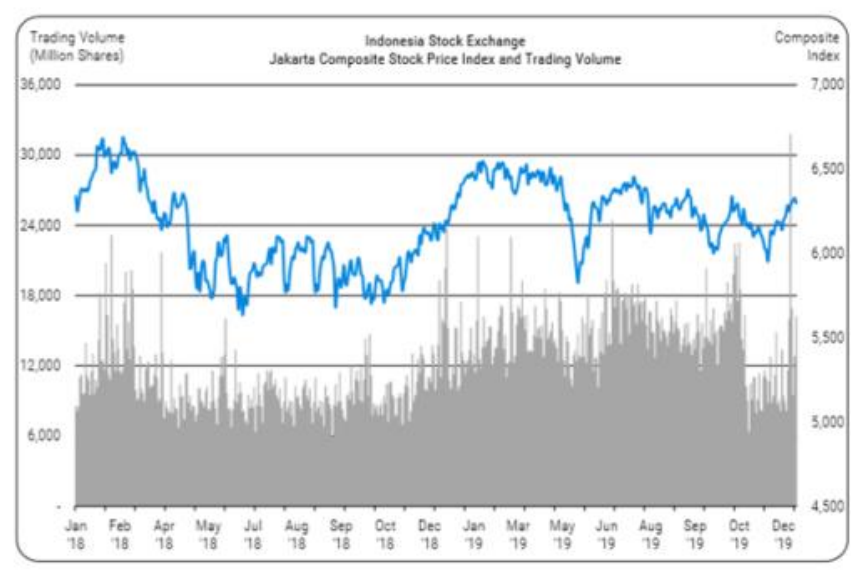

\section{Gambar 1}

\section{Jakarta Composite Stock Price Index and} Trading Volume

Sumber: http://www.idx.co.id

Pada Gambar 1 di atas dapat dilihat bahwa sejak tahun 2018 Indeks harga saham gabungan Indonesia sudah mengalami fluktuasi. Kemudian di semester I/2020 kinerja Indeks Harga Saham Gabungan mengalami penurunan paling rendah dalam 18 tahun terakhir. Berdasarkan data Bloomberg pergerakan IHSG 
tercatat mengalami koreksi 22,13 persen. Kinerja IHSG tersebut juga menjadi yang terendah dibanding dengan indeks saham lain di kawasan Asia Pasifik secara year to date. Hampir semua sektor saham yang terdaftar di BEI mengalami penurunan harga. Antara lain sektor keuangan, sektor aneka industri, perdagangan, agrobisnis, properti, pertambangan, infrastruktur, dan manufaktur (Pratomo, 2020).

Salah satu faktor yang menjadi penurunan IHSG di tahun 2019 adalah earning per share (EPS) atau laba per lembar saham emiten di BEI yang kurang mengesankan. Kondisi EPS yang rendah dipengaruhi oleh penyaluran kredit. Penyaluran kredit paling besar ada pada sektor perdagangan, pertanian, dan industri pengolahan seperti manufaktur. Namun di tahun 2019 ketiga sektor tersebut memiliki pertumbuhan yang lemah sehingga berdampak pada harga saham perusahaan dan nilai IHSG (Intan, 2019).

Selain itu, beberapa perusahaan mengalami penurunan harga saham yang diakibatkan oleh kondisi rasio keuangan perusahaan yang kurang baik. Antara lain pergerakan harga saham PT Acset Indonusa Tbk (ACST) yang telah turun $62,53 \%$ ke level Rp 296. Penurunan tersebut sejalan dengan kinerja yang mengalami penurunan dari 2018 dan di tahun 2019 bahkan mencatat kerugian. Pada tahun 2018 dan 2019 Acset mencatat kenaikan beban umum dan administrasi, kenaikan beban pajak final dan kenaikan biaya keuangan. Dan Debt to Equity Ratio (DER) yang meningkat dari tahun 2019 sebesar 5,26 kali menjadi 35,47 kali dan Debt to Asset Ratio (DAR) dari 0,84 kali menjadi 0,97 kali, buruknya kinerja perusahaan tersebut membuat tren penurunan harga saham ACST terus terjadi (Prima, 2020).

Penurunan harga saham juga terjadi pada saham PGAS dan disebabkan oleh beberapa faktor antara lain yaitu pendapatan dan laba bersih PGAS yang menurun sejak 2018 yang diakibatkan oleh kenaikan beban di luar beban operasi, penurunan nilai aset tetap dan provisi atas sengketa pajak. Kemudian penyebab lainnya adalah profit margin dan Return On Equity PGAS yang turun. ROE digunakan untuk mengukur kemampuan perusahaan dalam menghasilkan laba dari investasi pemegang saham dan NPM digunakan untuk mengukur seberapa efisien manajemen mengelola dalam menghasilkan laba bersih. Dan sejak 2012 hingga 2019 kedua rasio mengalami tren negatif. Penyebab selanjutnya adalah utang PGAS yang tinggi. Tren kenaikan DER ini terjadi dari tahun 2012, di mana di tahun 2012 rasio berada di level 0,48 kali, dan di 2014 angka DER lebih dari 0,5 dan di atas 1 di tahun 2018 (Girsang, 2020).

Karena adanya faktor-faktor yang dapat mempengaruhi perubahan harga saham maka investor perlu memperhatikan faktor tersebut sebelum menginvestasikan dananya pada saham (Ariyani et al., 2018). Dengan begitu investor dapat menganalisis kinerja perusahaan dan meramalkan kondisi harga saham di masa mendatang. Faktor-faktor yang dapat mempengaruhi harga saham tersebut juga terlah dilakukan penelitian oleh beberapa peneliti, antara lain; penelitian oleh Utami \& Darmawan (2019) bahwa MVA berpengaruh terhadap harga saham. Sriwahyuni \& Saputra (2017) 
EPS memiliki pengaruh signifikan terhadap harga saham, dan Munira et al., (2018) menyatakan jika DER berpengaruh terhadap harga saham dan ROE tidak memiliki pengaruh sedangkan penelitian Djazuli, (2017) justru menyatakan ROE memiliki pengaruh dan DER tidak berpengaruh terhadap harga saham.

Melihat pentingnya melakukan analisis melalui faktor-faktor yang dapat menjadi penyebab perubahan harga saham di masa depan. Dan hasil beberapa penelitian terkait yang masih ditemukan celah penelitian. Maka melalui tulisan ini akan diukur bagaimana pengaruh Rasio Utang Terhadap Ekuitas, Rasio Pengembalian Modal Dan Rasio Laba Per Lembar Saham terhadap Harga Saham pada Perusahaan Sektor Keuangan yang Terdaftar di BEI Pada Periode Tahun 2019. Hasil pengukuran ini dapat menjelaskan faktor penentu harga saham pada sektor keuangan yang terdaftar di BEI.

\section{TINJAUAN TEORI}

\section{Harga Saham}

Saham dapat didefinisikan sebagai tanda penyertaan atau kepemilikan investor individual atau investor institusional atau trader atas investasi mereka atau sejumlah dana yang diinvestasikan dalam suatu perusahaan (Aziz et al., 2015). Karakteristik saham antara lain dapat memperoleh dividen, memiliki Hak Memesan Efek dengan Terlebih Dahulu (HMETD) atau right issue, dan terdapat potensi capital gain atau capital loss (Aziz et al., 2015). Sedangkan menurut (Jogiyanto, 2010) Harga saham adalah Harga saham yang terjadi di pasar bursa pada saat tertentu yang ditentukan oleh pelaku pasar dan ditentukan oleh permintaan dan penawaran saham yang bersangkutan di pasar modal.

Menurut Tandelilin untuk mendeteksi dan menganalisis pergerakan harga saham baik saham individual maupun seluruh saham di pasar modal menggunakan teknik rata-rata bergerak. Tujuan penggunaan teknik ini adalah untuk mendeteksi arah pergerakan harga saham dan besarnya tingkat pergerakan tersebut (Tandelilin, 2017). Dalam perhitungan rata-rata bergerak, maka data yang dipakai adalah data harga penutupan saham (closing price) untuk waktu tertentu.

\section{Rasio Utang Terhadap Ekuitas}

Rasio utang terhadap ekuitas merupakan rasio yang menggambarkan perbandingan kewajiban dengan ekuitas dalam pendanaan perusahaan dan menunjukkan kemampuan modal sendiri perusahaan tersebut untuk memenuhi seluruh kewajiban (John, Fred \& Copeland, 1997). Menurut Hantono (2018) Rasio Utang terhadap Modal (DER) adalah rasio yang menunjukkan sejauh mana modal sendiri menjamin seluruh utang. Rasio ini juga dapat dibaca sebagai perbandingan antara dana pihak luar dengan dana pemilik perusahaan. Teori tersebut sejalan dengan Damodaran (2012) yang menyimpulkan bahwa hutang merupakan sebagai bagian dari nilai buku ekuitas perusahaan dan dapat ditentukan dengan mudah sedari awal. Meskipun modal pada rasio ini dianggap hanya dari utang dan ekuitas, tapi rasio ini juga dapat dengan mudah disesuaikan untuk memasukkan sumber keuangan lain, seperti saham preferen. 
Mei Tresnawati, Achmad Fauzi, dan Mardi/ Jurnal Ilmiah Wahana Akuntansi, 16 (1) 2021, 111-123

Menghitung DER dalam penelitian ini merujuk pada (Aziz et al., 2015), yaitu:

$$
D E R=\frac{\text { Total Debt }}{\text { Total Shareholder'sEquity }}
$$

\section{Rasio Pengembalian Modal}

Return on Equity merupakan rasio yang menunjukkan seberapa bagus manajemen dalam mengelola aset perusahaan dan memberikan keuntungan bagi pemegang saham (Iman, 2013:51). Menurut Kasmir, hasil Pengembalian Ekuitas atau Return on Equity atau rentabilitas modal sendiri, merupakan rasio untuk mengukur laba bersih sesudah pajak dengan modal sendiri. Rasio ini menunjukkan efisiensi penggunaan modal sendiri. Semakin tinggi rasio ini, maka semakin baik, artinya posisi perusahaan semakin kuat, demikian pula sebaliknya (Kasmir, 2019). Syamsuddin (2016) juga menjelaskan bahwa ROE merupakan suatu pengukuran dari penghasilan yang tersedia bagi para pemilik perusahaan (baik pemegang saham biasa maupun pemegang saham preferen) atas modal yang mereka investasikan di dalam perusahaan.

Menurut Kasmir (2019:137) menghitung besarnya Return on Equity (ROE) dapat digunakan pendekatan sebagai berikut:

$$
\text { Return on Equity }(R O E)=\frac{\text { Earning After Interest and Tax }}{\text { Equity }}
$$

\section{Laba per Lembar Saham}

Menurut Kasmir (2019:115) Rasio Laba Per Lembar Saham (Earnings Per Share) disebut sebagai rasio nilai buku, yaitu rasio untuk mengukur keberhasilan manajemen dalam mencapai keuntungan bagi pemegang saham.
Menurut Syamsuddin (2016), Earning per Share merupakan rasio yang banyak diperhatikan oleh calon investor, karena informasi Earning per Share merupakan informasi yang dianggap paling mendasar dan dapat menggambarkan prospek earning perusahaan masa depan.

Menurut Darya Putu (2019:154) Earning per share merupakan rasio profitabilitas yang meningkatkan tingkat kemampuan per lembar saham dalam menghasilkan laba untuk perusahaan. Menentukan besaran earning per share menggunakan pendekatan sebagai berikut (Hantono, 2018):

$$
\mathrm{EPS}=\frac{\text { Laba Saham Biasa }}{\text { Jumlah saham biasa yang beredar }}
$$

\section{Pengaruh DER Terhadap Harga Saham}

Mohamad Samsul (2015) menjelaskan faktor mikro ekonomi yang mempunyai pengaruh terhadap harga saham suatu perusahaan berada di dalam perusahaan itu sendiri yaitu: laba bersih per saham, laba usaha per saham, nilai buku per saham, rasio ekuitas terhadap utang, rasio laba bersih terhadap ekuitas, dan cash flow per saham.

Selain itu menurut (Eugene F \& Houston, 1999) DER yang rendah dapat meningkatkan respon positif dari pasar dan akan semakin baik kemampuan perusahaan dalam membayar kewajiban jangka panjang karena risiko yang ditimbulkan dari penggunaan pendanaan yang bersumber dari hutang akan berkurang, sehingga saham naik, oleh karena itu DER memiliki pengaruh negatif terhadap harga saham. 
Mei Tresnawati, Achmad Fauzi, dan Mardi/ Jurnal Ilmiah Wahana Akuntansi, 16 (1) 2021, 111-123

Berdasarkan penjelasan di atas maka hipotesis pertama dari penelitian ini adalah:

$\mathrm{H}_{1}$ : Debt to Equity Ratio berpengaruh terhadap harga saham.

\section{Pengaruh ROE Terhadap Harga Saham}

Brigham \& Houston (2013) menyatakan bahwa "Investors like a high ROE, and high ROEs are correlated with high stock prices." Yang berarti bahwa investor menyukai ROE yang tinggi, dan ROE yang tinggi berhubungan dengan harga saham yang tinggi. (Khan, 2002) juga menyatakan bahwa ROE yang tinggi dimaknai dengan harga saham yang tinggi, dan perusahaan yang mempunyai ROE yang tinggi seperti intel dan Microsoft secara luas harga saham mereka akan lebih dihargai.

Berdasarkan penjelasan di atas maka hipotesis kedua dari penelitian ini adalah:

$\mathrm{H}_{2}$ : Return On Equity berpengaruh terhadap harga saham.

\section{Pengaruh EPS Terhadap Harga Saham}

Darmadji \& Fakhruddin,

(2012) menyatakan bahwa secara teori semakin tinggi EPS, harga saham cenderung naik. EPS yang meningkat akan mendorong investor untuk menambah jumlah modal yang ditanamkan pada perusahaan tersebut, sehingga permintaan terhadap saham tersebut meningkat yang berakibat harga saham juga meningkat. (Widoatmodjo, 2008) juga menyatakan bahwa di dalam perdagangan saham, EPS sangat berpengaruh pada harga pasar saham. Semakin tinggi EPS, maka semakin tinggi harga saham tersebut, dan sebaliknya.
Berdasarkan penjelasan di atas maka hipotesis ketiga dari penelitian ini adalah:

$\mathrm{H}_{3}$ : Earnings Per Share berpengaruh terhadap harga saham.

\section{METODE PENELITIAN}

Penelitian ini menggunakan pendekatan kuantitatif yang merupakan metode penelitian yang berlandaskan pada filsafat positivisme, digunakan untuk meneliti pada populasi dan sampel tertentu, pengumpulan data menggunakan instrumen penelitian, analisis data bersifat kuantitatif/statistik, dengan tujuan untuk menguji hipotesis yang telah ditetapkan. (Sugiyono, 2015).

Pengumpulan data penelitian berdasarkan informasi yang sudah tersedia dalam bentuk laporan keuangan dan data harga saham pada website www.idx.co.id. Data laporan keuangan perusahaan sektor keuangan periode 2019 sedangkan data harga saham yang digunakan adalah harga saham penutupan setelah penerbitan laporan keuangan, satu bulan setelah batas akhir penyampaian laporan keuangan (April 2020).

Populasi penelitian sebanyak 90 perusahaan di BEI. Penentuan sampel menggunakan purposive sampling, dengan kriteria seperti yang disajikan pada Tabel 1.

Penelitian ini menjadikan Harga Saham sebagai variabel dependen. Sedangkan variabel independennya terdiri dari DER, ROE, dan EPS. Operasionalisasi variabel disajikan pada Tabel 2. 
Tabel 1

Kriteria Penentuan Sampel

\begin{tabular}{|c|c|c|}
\hline No & Kriteria & $\begin{array}{l}\text { Jumlah } \\
\text { Perusahaan }\end{array}$ \\
\hline 1 & $\begin{array}{l}\text { Perusahaan yang terdaftar di } \\
\text { BEI tahun } 2019\end{array}$ & 90 \\
\hline 2 & $\begin{array}{l}\text { Perusahaan yang tidak } \\
\text { menerbitkan laporan keuangan } \\
\text { tahunan pada periode } \\
\text { pengamatan yaitu periode tahun } \\
2019\end{array}$ & (3) \\
\hline 3 & $\begin{array}{l}\text { Perusahaan yang memiliki harga } \\
\text { saham rata-rata lebih dari } \\
\text { Rp5.000 }\end{array}$ & (9) \\
\hline 4 & $\begin{array}{l}\text { Perusahaan yang tidak memiliki } \\
\text { saldo laba (retained earnings) } \\
\text { positif. }\end{array}$ & (15) \\
\hline 5 & $\begin{array}{l}\text { Perusahaan yang tidak } \\
\text { menyediakan data sesuai dengan } \\
\text { variabel penelitian }\end{array}$ & (0) \\
\hline \multicolumn{2}{|c|}{$\begin{array}{l}\text { Jumlah perusahaan yang layak } \\
\text { diobservasi sebanyak }\end{array}$} & 63 \\
\hline \multicolumn{2}{|c|}{ Tahun Pengamatan } & 1 \\
\hline \multicolumn{2}{|c|}{ Data Outlier } & (6) \\
\hline \multicolumn{2}{|c|}{ Total Sampel Akhir } & 57 \\
\hline
\end{tabular}

Tabel 2

Operasionalisasi Variabel

\begin{tabular}{|c|c|c|}
\hline Variabel & Definisi Konseptual & $\begin{array}{c}\text { Definisi } \\
\text { Operasional }\end{array}$ \\
\hline $\begin{array}{l}\text { Harga } \\
\text { Saham } \\
\text { (Y) }\end{array}$ & $\begin{array}{l}\text { Harga pada suatu saham } \\
\text { yang terbentuk di pasar } \\
\text { modal yang sedang } \\
\text { berlangsung }\end{array}$ & Closing Price \\
\hline $\begin{array}{l}\text { Debt to } \\
\text { Equity } \\
\text { Ratio } \\
\left(\mathrm{X}_{1}\right)\end{array}$ & $\begin{array}{l}\text { Rasio yang menunjukkan } \\
\text { perbandingan hutang } \\
\text { perusahaan dengan modal } \\
\text { milik perusahaan. }\end{array}$ & $D E R=\frac{\text { Total Debt }}{\text { Equity }}$ \\
\hline $\begin{array}{l}\text { Return on } \\
\text { Equity } \\
\left(\mathrm{X}_{2}\right)\end{array}$ & $\begin{array}{l}\text { Merupakan rasio untuk } \\
\text { menggambarkan } \\
\text { kemampuan perusahaan } \\
\text { mengelola modalnya } \\
\text { sendiri untuk mampu } \\
\text { menghasilkan laba. }\end{array}$ & 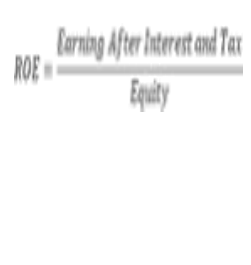 \\
\hline $\begin{array}{l}\text { Earnings } \\
\text { Per Share } \\
\quad\left(\mathrm{X}_{3}\right)\end{array}$ & $\begin{array}{l}\text { Merupakan rasio yang } \\
\text { menunjukkan pendapatan } \\
\text { yang akan diperoleh setiap } \\
\text { pemegang saham untuk } \\
\text { setiap lembar saham yang } \\
\text { dimilikinya }\end{array}$ & 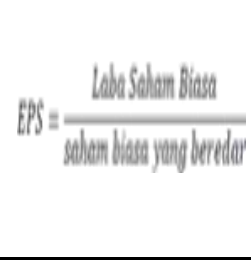 \\
\hline
\end{tabular}

Sumber: Data diolah oleh penulis, Tahun 2021

\section{Teknik Analisis Data}

Teknik Analisis Data dalam penelitian ini menggunakan uji statistik deskriptif. Dan dilanjutkan dengan melakukan pengujian persyaratan analisis dan uji asumsi klasik. Selanjutnya Uji Hipotesis dilakukan dengan menggunakan: (1) Uji koefisien determinasi; (2) Uji keberartian regresi (Uji F) yang bertujuan untuk menguji apakah model regresi yang digunakan fit; dan (3) Uji t (Parsial) untuk menunjukkan seberapa jauh pengaruh satu variabel penjelas/independen secara individual dalam menerangkan variasi variabel dependen (Ghozali, 2016:98).

\section{HASIL DAN \\ PENELITIAN}

\section{Statistik Deskriptif}

Deskripsi data hasil penelitian menyajikan gambaran umum mengenai penyebaran atau distribusi data yang diperoleh dari variabel yang digunakan dalam penelitian. Dalam penelitian ini terdapat empat variabel, yaitu tiga variabel bebas dan satu variabel terikat. Variabel bebas yaitu variabel yang mempengaruhi, antara lain, rasio utang terhadap modal (debt to equity ratio) $\left(\mathrm{X}_{1}\right)$, rasio pengembalian modal (return on equity) $\left(\mathrm{X}_{2}\right)$ dan laba per saham (earnings per share) $\left(\mathrm{X}_{3}\right)$. Sedangkan untuk variabel terikat yaitu harga saham (Y).

Berdasarkan hasil pengujian statistik deskriptif atas satu variabel dependen dan tiga variabel independen, maka diperoleh hasil statistik deskriptif seperti yang disajikan pada Tabel 3. 
Mei Tresnawati, Achmad Fauzi, dan Mardi / Jurnal Ilmiah Wahana Akuntansi, 16 (1) 2021, 111-123

Tabel 3

Statistik Deskriptif - Sebelum Outlier

\begin{tabular}{lrrrrr}
\hline & N & Min & Max & Mean & $\begin{array}{c}\text { Std. } \\
\text { Deviation }\end{array}$ \\
\hline Harga Saham & 63 & 50,00 & 4111,43 & 821,3167 & 1001,31 \\
DER & 63 & 0,01 & 13,54 & 3,7796 & 3,25 \\
ROE & 63 & 0,00 & 0,26 & 0,0682 & 0,05673 \\
EPS & 63 & 0,32 & 825,00 & 96,1409 & 159,57 \\
Valid N & 63 & & & & \\
(listwise) & 63 & & & & \\
\hline
\end{tabular}

Sumber: Data diolah oleh penulis, Tahun 2021

Pada proses pengolahan data, dari 63 data observasi terdapat enam data outlier, sehingga 6 data outlier tersebut harus dikeluarkan dari analisis penelitian ini. Ghozali (2016) menyebutkan bahwa outlier merupakan kasus atau data yang memiliki karakteristik unik yang terlihat sangat berbeda jauh dari observasiobservasi lainnya dan muncul dalam bentuk nilai ekstrem baik untuk sebuah variabel tunggal atau kombinasi. Uji outlier dilakukan dengan melihat grafik boxplot, angka-angka yang terletak di luar boxplot merupakan angka observasi yang perlu dihilangkan. Setelah dilakukan pembuangan data outlier jumlah data yang diobservasi menjadi 57.

Tabel 4 di bawah ini merupakan statistik deskriptif untuk data yang telah dilakukan pengeluaran data outlier.

Tabel 4

Statistik Deskriptif - Setelah Outlier

\begin{tabular}{lrrrrr}
\hline & N & Min & Max & Mean & $\begin{array}{c}\text { Std. } \\
\text { Deviation }\end{array}$ \\
\hline Harga Saham & 57 & 50,00 & 3720,00 & 700,8680 & 820,28 \\
DER & 57 & 0,01 & 11,33 & 3,3108 & 2,61 \\
ROE & 57 & 0,00 & 0,19 & 0,0749 & 0,056 \\
EPS & 57 & 0,32 & 533,00 & 77,8133 & 116,12 \\
Valid N & 57 & & & & \\
(listwise) & & & & & \\
\hline
\end{tabular}

Sumber: Data diolah oleh penulis, Tahun 2021

\section{Hasil Uji Asumsi Klasik}

Uji normalitas pada penelitian ini menggunakan uji Kolmogorov Smirnov. Dari hasil pengolahan data menunjukkan angka 0,760 lebih tinggi dari tingkat signifikansi 0,05 yang berarti data terdistribusi normal.

Untuk hasil uji multikolinearitas menunjukkan nilai tolerance semua variabel penelitian lebih dari 0,10 dan nilai VIF semua variabel kurang dari 10 sehingga disimpulkan tidak terjadi gejala multikolinearitas.

Uji Heteroskedastisitas dilakukan dengan menggunakan grafik scatterplot dan dari hasil uji titik-titik pada scatter plot menyebar di atas dan di bawah angka 0 pada sumbu $\mathrm{Y}$, begitupun jika dilihat dengan sumbu $\mathrm{X}$, scatter plot menyebar di sekitar titik 0 serta ke kiri dan kanan, sehingga dapat disimpulkan penelitian terbebas dari persoalan heteroskedestisitas.

Sedangkan untuk uji autokorelasi dilakukan dengan menggunakan kaidah nilai Durbin Watson, di mana hasilnya menunjukkan nilai DW (2,074) lebih kecil dari 4-DU $(2,3155)$ yang berarti tidak ada gejala autokorelasi.

\section{Hasil Uji Persamaan Regresi}

Persamaan regresi penelitian ini disusun berdasarkan hasil pada Tabel 5, dengan hasil persamaan regresi adalah sebagai berikut:

$$
\mathrm{Y}=6,216+0,039 \mathrm{X}_{1}+0,337 \mathrm{X}_{2}+0,238 \mathrm{X}_{3}
$$

Persamaan di atas dapat diinterpretasikan sebagai berikut: (1) Koefisien konstanta $(\alpha)$ sebesar 6,216, ini berarti apabila nilai DER, ROE dan EPS pada objek penelitian sama dengan nol, maka harga saham bernilai 6,216; (2) Nilai rasio utang/DER sebesar 0,039 berarti 
rasio utang terhadap modal mengalami kenaikan sebesar satu satuan, maka harga saham akan mengalami peningkatan sebesar 0,039; (3) Nilai tingkat pengembalian modal/ROE sebesar 0,337 berarti rasio pengembalian modal mengalami kenaikan sebesar satu satuan maka harga saham akan mengalami peningkatan sebesar 0,337 ; dan (4) Jika nilai pendapatan per saham/EPS sebesar 0,238 berarti rasio laba per saham mengalami kenaikan sebesar satu satuan, sementara variabel lain bersifat tetap maka harga saham akan mengalami peningkatan sebesar 0,238.

Tabel 5

Hasil Uji Analisis Regresi Berganda

\begin{tabular}{|c|c|c|c|c|c|}
\hline \multirow{2}{*}{ Model } & \multicolumn{2}{|c|}{$\begin{array}{l}\text { Unstandardized } \\
\text { Coefficients }\end{array}$} & \multirow{2}{*}{$\begin{array}{c}\begin{array}{c}\text { Standardized } \\
\text { Coefficients }\end{array} \\
\text { Beta }\end{array}$} & \multirow{2}{*}{$\mathbf{t}$} & \multirow{2}{*}{ Sig. } \\
\hline & B & $\begin{array}{l}\text { Std. } \\
\text { Error }\end{array}$ & & & \\
\hline \multirow{4}{*}{$\begin{array}{ll} & \text { (Con } \\
& \text { DER } \\
\text { ROE } \\
\text { EPS }\end{array}$} & 6,216 & 0,725 & & 8,576 & 0,000 \\
\hline & 0,039 & 0,073 & 0,053 & 0,533 & 0,596 \\
\hline & 0,337 & 0,160 & 0,336 & 2,103 & 0,040 \\
\hline & 0,238 & 0,092 & 0,409 & 2,574 & 0,013 \\
\hline
\end{tabular}

Sumber: Data diolah oleh penulis, Tahun 2021

\section{Hasil Uji t}

Dari Tabel 5 di atas dapat dilihat bahwa rasio utang terhadap modal memiliki nilai sig 0,596, lebih besar dari nilai 0,05, maka dapat disimpulkan bahwa hipotesis pertama tidak diterima. Rasio utang terhadap modal, $t$ hitung $(0,533)$ lebih kecil dari $t$ tabel $(2,0057)$. Disimpulkan rasio utang terhadap modal tidak memiliki kontribusi terhadap harga saham.

Pada Tabel 5 juga menunjukkan bahwa rasio pengembalian modal memiliki nilai sig 0,040, di mana nilai ini lebih kecil dari nilai 0,05. Sehingga dapat disimpulkan bahwa hipotesis kedua diterima. Rasio pengembalian modal, $t$ hitung $(2,103)$ lebih besar dari t tabel $(2,0057)$. Disimpulkan ROE memiliki kontribusi terhadap harga saham.

Selain itu, hasil pada Tabel 5 juga menunjukkan bahwa rasio laba per saham (Earnings per Share) memiliki nilai sig 0,013 lebih kecil dari nilai 0,05 , hipotesis diterima. Rasio laba per saham dengan $t$ hitung $(2,574)$ lebih besar dari t tabel $(2,0057)$. Disimpulkan rasio laba per saham memiliki kontribusi terhadap harga saham.

\section{Hasil Uji Koefisien Determinasi}

Hasil uji koefisien determinasi dari penelitian ini disajikan pada Tabel 6 di bawah ini.

Tabel 6

Hasil Uji Koefisien Determinasi

\begin{tabular}{lrrrr} 
Model & $\mathbf{R}$ & $\begin{array}{c}\text { R } \\
\text { Square }\end{array}$ & $\begin{array}{c}\text { Adjusted } \\
\text { R Square }\end{array}$ & $\begin{array}{c}\text { Std. Error } \\
\text { of the } \\
\text { Estimate }\end{array}$ \\
\hline 1 & 0,704 & 0,496 & 0,467 & 0,85519 \\
\hline
\end{tabular}

Sumber: Data diolah oleh penulis, Tahun 2021

Berdasarkan pada Tabel 6 di atas nilai korelasi ganda $\mathrm{R}$ adalah 0,704 yang menunjukkan adanya hubungan yang kuat antara rasio utang, rasio pengembalian modal dan pendapatan per saham terhadap harga saham. Sedangkan R square adalah sebesar 0.496 menggambarkan pengaruh rasio utang, rasio pengembalian modal dan pendapatan per saham terhadap harga saham pada perusahaan sektor keuangan di tahun 2019 sebesar 49,6\%, sedangkan sebesar 50,4\% disebabkan pengaruh dari faktor lain yang belum diprediksi dalam 
penelitian ini.

\section{Hasil Uji F}

Hasil uji F dari penelitian ini disajikan pada Tabel 7 di bawah ini.

Tabel 7

\section{Hasil Uji F}

\begin{tabular}{lrrrrr}
\hline Model & $\begin{array}{c}\text { Sum of } \\
\text { Squares }\end{array}$ & df & $\begin{array}{c}\text { Mean } \\
\text { Square }\end{array}$ & F & Sig. \\
\hline Regression & 38,129 & 3 & 12,710 & 17,378 & 0,000 \\
Residual & 38,762 & 53 & 0,731 & & \\
Total & 76,891 & 56 & & & \\
\hline
\end{tabular}

Sumber: Data diolah oleh penulis, Tahun 2021

Berdasarkan pada Tabel 7 di atas menunjukkan hasil pengujian $\mathrm{F}$ hitung $(17,378)$ dengan nilai sig $(0,000)$. Nilai $F$ hitung lebih besar dari $\mathrm{F}$ tabel $(2,78)$ dan nilai sig lebih kecil dari 0,05 maka hipotesis diterima, yang berarti bahwa model regresi fit.

\section{Pengaruh Debt to Equity Ratio Terhadap Harga Saham}

Rasio Modal terhadap Utang (Debt to Equity Ratio) tidak berpengaruh terhadap harga saham perusahaan sektor keuangan di BEI. Dapat diartikan tinggi atau rendahnya nilai rasio utang terhadap modal perusahaan di sektor keuangan tidak akan mempengaruhi harga saham perusahaan. bagi investor, besar atau kecilnya tingkat utang terhadap modal tidak akan berpengaruh secara signifikan terhadap keputusan pembelian saham jika perusahaan memiliki catatan pelunasan hutang yang baik. (Pratama et al., 2019). Kesimpulan ini sejalan dengan hasil penelitian Efrizon (2019) yang menyimpulkan bahwa tidak ada hubungan pengaruh negative dan signifikan antara variabel DER dengan harga saham, kemudian Pratama et al., (2019) juga menyimpulkan bahwa secara parsial DER tidak berpengaruh terhadap harga saham. Utami \& Darmawan (2019) menyatakan dari hasil penelitiannya dengan menggunakan eviews dan chow test dan Hausman test juga disimpulkan bahwa variabel DER tidak memiliki pengaruh signifikan terhadap harga saham. Hasil tersebut berbeda dengan penelitian oleh (Munira et al., 2018) yang menyimpulkan bahwa DER berpengaruh signifikan terhadap harga saham.

\section{Pengaruh Return On Equity Terhadap Harga Saham}

Tingkat pengembalian modal (Return on Equity) berpengaruh positif terhadap harga saham perusahaan sektor keuangan di BEI. Hal tersebut menunjukkan semakin tinggi nilai Return on Equity maka harga saham akan naik dan demikian sebaliknya. Hal ini dikarenakan Return on Equity pada sampel penelitian ini relatif tinggi sehingga dapat meningkatkan kepercayaan investor yang dampaknya pada peningkatan harga saham. Penelitian ini sejalan dengan kesimpulan yang dilakukan oleh (Adi et al., 2020) dengan kesimpulan bahwa ROE memiliki nilai pengaruh positif signifikan terhadap harga saham, (Pratama et al., 2019) dan (Christian \& Frecky, 2019) masing-masing menyimpulkan bahwa variabel ROE memiliki pengaruh yang signifikan dan positif terhadap harga saham. Sedangkan penelitian oleh (Qaisi et al., 2016) menyimpulkan bahwa tidak ada pengaruh antara variabel ROE dan harga 
saham.

\section{Pengaruh Earning Per Share Terhadap Harga Saham}

Pendapatan per saham (Earning per share) berpengaruh positif terhadap harga saham perusahaan sektor keuangan. Hal mana menunjukkan Earning per share berbanding lurus dengan harga saham, artinya jika nilai laba per saham meningkat maka harga saham juga akan meningkat. Hal tersebut dikarenakan nilai earning per share merupakan nilai atau total yang akan didapat oleh investor jika memiliki saham perusahaan sehingga dapat mempengaruhi persepsi investor, terutama dalam keputusan membeli saham perusahaan. Penelitian yang sama dengan penelitian yang dilakukan oleh Efrizon (2019) dengan kesimpulan bahwa terdapat hubungan yang signifikan antara variabel earning per share dengan harga saham., Pratama et al., (2019) dan Puspitaningtyas (2017) masing-masing menyimpulkan bahwa antara variabel EPS dan harga saham memiliki hubungan pengaruh yang signifikan. Sedangkan penelitian lain yang dilakukan oleh (Rahmadewi \& Abundanti, 2018) menyimpulkan bahwa variabel EPS memiliki hubungan negatif dan tidak signifikan terhadap harga saham.

\section{KESIMPULAN DAN SARAN}

Rasio utang terhadap modal tidak berpengaruh terhadap harga saham. Hal ini berarti tinggi ataupun rendah nilai DER pada laporan keuangan perusahaan di sektor keuangan tidak mencerminkan naik dan turunnya harga saham perusahaan. Sedangkan rasio pengembalian modal memiliki pengaruh signifikan terhadap harga saham. Berarti tinggi rendahnya nilai Return On Equity di laporan keuangan akan mempengaruhi tinggi rendahnya harga saham perusahaan sektor keuangan. Maka jika nilai Return On Equity meningkat maka harga saham juga akan meningkat. Earning per share berpengaruh positif terhadap harga saham, bahwa semakin tinggi nilai EPS dalam laporan keuangan akan meningkatkan harga saham perusahaan dan demikian sebaliknya semakin rendah nilai EPS maka harga saham semakin kecil.

Pada perusahaan sektor keuangan untuk selalu dapat menjaga catatan pelunasan hutang secara baik. Perusahaan juga harus terus meningkatkan dan menjaga rasio pengembalian modal dan nilai laba per saham untuk dapat mempengaruhi persepsi investor untuk membeli saham. Selain itu, perusahaan juga perlu memperhatikan faktor-faktor eksternal dan sentimen pasar guna memantau dan menstabilkan harga saham mereka di pasar. Dengan memperhatikan banyak faktor investor akan dapat meminimalisir risiko kerugian dari membeli saham tersebut.

\section{DAFTAR PUSTAKA}

Adi, A., Darminto, \& Armanto, D. (2020). PENGARUH RETURN ON EQUITY, DEBT TO EQUITY RATIO, EARNING PER SHARE DAN BOOK VALUE PER SHARE TERHADAP HARGA SAHAM. Akuntansi : Jurnal Akuntansi Integratif, 6 (01), 25-39. https://doi.org/10.29080/ jai.v6i01.241 
Ariyani, L., Andini, R., \& Santoso, E. B. (2018). Pengaruh EPS, CR, DER Dan PBV Terhadap Harga Saham Dengan Kebijakan Dividen Sebagai Variabel Intervening (Studi pada Perusahaan Manufaktur yang Terdaftar di BEI Tahun 2011-2015. Journal Of Accounting, 4(4), 1-20. http:// jurnal.unpand.ac.id/index.php/AKS/article/ view/958

Astawinetu, E. D., \& Handini, S. (2020). Manajemen Keuangan: Teori dan Praktik. Surabaya: Scopindo Media Pustaka.

Aziz, M., Mintarti, S., \& Nadir, M. (2015). Manajemen Investasi. Yogyakarta: Deepublish.

Brigham, E. F., \& Houston, J. F. (2013). Fundamentals of Financial Management. South-Western: Cengage Learning.

Christian, N., \& Frecky, F. (2019). Analisis Pengaruh Faktor-Faktor Yang Mempengaruhi Harga Saham Pada Perusahaan Yang Terdaftar Di Bursa Efek Indonesia. Jurnal Benefita, 1(1), 115. https://doi.org/10.22216/jbe.v1i1.3417

Damodaran, A. (2012). Investment Valuation (Tools and Techniques for Determining the Value of Any Assets). New York: Wiley.

Darmadji, \& Fakhruddin, H. M. (2012). Pasar Modal di Indonesia. Pendekatan Tanya Jawab. Jakarta: Salemba Empat.

Darya Putu, I Gusti. (2019). Akuntansi Manajemen. Ponorogo: Uwais Inspirasi Indonesia.

Djazuli, A. (2017). The Relevance of Leverage , Profitability, Market Performance, and Macroeconomic to Stock Price. Ekonomi Bisnis, 22(2), 112-122.

Dr. Sri Handini, MM , Dra. Erwin Dyah Astawinetu, M. (2020). TEORI PORTOFOLIO DAN PASAR MODAL INDONESIA. Jakarta: Scopindo Media Pustaka.

Efrizon, E. (2019). Pengaruh Rasio Keuangan Terhadap Harga Saham Perusahaan
Otomotif Periode 2013-2017. Jurnal Akuntansi Aktual, 5(3), 250-260. https:// doi.org/10.17977/um004v5i32019p250

Eugene F, B., \& Houston, J. F. (1999). Manajemen Keuangan. Jakarta: Erlangga.

Ghozali, I. (2016). Aplikasi Analisis Multivariete dengan Program IBM SPSS 23. Semarang: Badan Penerbit Universitas Diponegoro.

Girsang, Y. (2020). Penyebab Harga Saham PT Perusahaan Gas Negara Anjlok. Tagar.Id.

Hantono. (2018). Konsep Analisa Laporan Keuangan dengan Pendekatan Rasio dan SPSS. Yogyakarta: Deepublish.

Iman, N. (2013). Kiat-kiat Membiakkan Uang di Masa Sulit. Jakarta: Elex Media Komputindo.

Intan, K. (2019). Kinerja IHSG sepanjang tahun ini kurang memuaskan, bagaimana tahun depan? Kontan.Co.Id.

Jogiyanto, H. (2010). Teori Portofolio dan Analisis Investasi. Edisi Keenam. Yogyakarta: BPFE.

John, Fred, W., \& Copeland. (1997). Manajemen Keuangan. Jakarta: Binarupa.

Kasmir. (2019). Pengantar Manajemen Keuangan Edisi Kedua. Jakarta: Kencana.

Khan, A. (2002). 501 Stock Market Tips and Guidelines. USA: iUniverse,Inc.

Munira, M., Merawati, E. E., \& Astuti, S. B. (2018). Pengaruh ROE dan DER terhadap Harga Saham Perusahaan Kertas di Bursa Efek Indonesia. JABE (Journal of Applied Business and Economic), 4(3), 191. https://doi.org/10.30998/jabe.v4i3.2478

Pratama, C. A., Devi Farah Azizah, \& Nurlaily, F. (2019). PENGARUH RETURN ON EQUITY (ROE), EARNING PER SHARE (EPS), CURRENT RATIO (CR) DAN DEBT TO EQUITY RATIO (DER) TERHADAP HARGA SAHAM. 
Mei Tresnawati, Achmad Fauzi, dan Mardi/ Jurnal Ilmiah Wahana Akuntansi, 16 (1) 2021, 111-123

Business Administration Journal, 66(1), 10 -17 .

administrasibisnis.studentjournal.ub.ac.id

Pratomo, N. (2020). Rapor Merah IHSG Semester I/2020, Koreksi Terbesar dalam 18 Tahun! Bisnis.Com. https:// market.bisnis.com/ $\mathrm{read} / 20200630 / 7 / 1259594 /$ rapor-merahihsg-semester-i2020-koreksi-terbesardalam-18-tahun

Prima, B. (2020). Analis: Penurunan harga saham Acset Indonusa (ACST) sejalan dengan peningkatan utang. Kontan.Co.Id. https://investasi.kontan.co.id/news/analispenurunan-harga-saham-acset-indonusaacst-sejalan-dengan-peningkatan-utang? page $=$ all

Puspitaningtyas, Z. (2017). Is Financial Performance Reflected in Stock Prices? December. https://doi.org/10.2991/icame17.2017.2

Putra, M., \& Yadnya, I. (2016). Penerapan Metode Capital Asset Pricing Model Sebagai Pertimbangan Dalam Pengambilan Keputusan Investasi Saham. E-Jurnal Manajemen Universitas Udayana, 5(12), 255270.

Qaisi, F. Al, Al-qudah, M., \& Tahtamouni, D. A. (2016). Factors Affecting the Market Stock Price - The Case of the Insurance Companies Listed in Amman Stock Exchange. International Journal of Business and Social Science, 7(10), 81-90.

Rahmadewi, P. W., \& Abundanti, N. (2018). Pengaruh Eps, Per, Cr Dan Roe Terhadap Harga Saham Di Bursa Efek Indonesia. EJurnal Manajemen Universitas Udayana, 7 (4), 2106. https://doi.org/10.24843/ ejmunud.2018.v07.i04.p14

Samsul, M. (2015). Pasar Modal dan Manajemen Portfolio. Jakarta: Erlangga.

Sriwahyuni, E., \& Saputra, R. (2017). Pengaruh CR, DER, ROE, TAT, dan EPS terhadap Harga Saham Industri Farmasi di BEI Tahun 2011-2015. Jurnal Online Insan Akuntan, 2(1), 234090.
Sugiyono. (2015). Metode Penelitian \& Pengembangan: Research and Development. Alfabeta.

Sunaryo, D. (2019). MANAJEMEN INVESTASI DAN PORTOFOLIO. Pasuruan: CV. Penerbit Qiara Media.

Syamsuddin, L. (2016). Manajemen Keuangan Perusahaan: Konsep Aplikasi dalam Perencanaan, Pengawasan, dan Pengambilan Keputusan. Jakarta: PT. Raja Grafindo Persada.

Tandelilin, E. (2017). Pasar modal: manajemen portofolio \& investasi ( $\mathrm{G}$. Sudibyo (ed.)). Yogyakarta: PT. Kanisius.

Utami, M. R., \& Darmawan, A. (2019). Effect of DER, ROA, ROE, EPS and MVA on Stock Prices in Sharia Indonesian Stock Index. Journal of Applied Accounting and Taxation, 4(1), 15-22. https:// doi.org/10.30871/jaat.v4i1.1195

Widioatmodjo, S. (2014). Cara Cepat Investasi Saham Pemula (Revisi). Jakarta: Elex Media Komputindo.

Widioatmodjo, S. (2015). Pengetahuan Pasar Modal Untuk Konteks Indonesia (R. L. Toruan (ed.); 1st ed.). Jakarta: Elex Media Komputindo.

Widoatmodjo, S. (2008). Seri Membuat Uang Bekerja Untuk Anda Cara Sehat Investasi di Pasar Modal. Jakarta: Gramedia.

Zulfikar. (2016). Pengantar Pasar Modal dengan Pendekatan Statistika (1st ed.). Yogyakarta: Deepublish 